\title{
NO-FAULT INSURANCE AND THE CONFLICT OF LAWS-AN INTERIM UPDATE
}

\author{
P. JOHN KOZYRIS*
}

In an article published in the Duke Law Journal in June of 1972, Professor Kozyris proposed a choice of law system for no-fault which would resolve in a novel way the confusion engendered by disparate state approaches to the problems of compensation and liability for injuries resulting from automobile accidents, by tying the extent and nature of both the victim's recovery and the driver's liability to the respective laws of their states of domicil-regardless of the place of the accident. During the period subsequent to the publication of that article, the proposed "federal standard" no-fault bill has been modified to reflect substantial deference to the domiciliary concept in its choice of law provisions, while the various state plans adopted have continued to reflect a notable preference for a territorialist approach. In this article, Professor Kozyris favorably analyzes the choice of law provisions of the proposed federal bill. In a less encouraging vein, his demonstration of the anomalous results generated by the territorialism of some of the recently enacted state plans suggests that a rational and consistent choice of law scheme for the interstate automobile accident may be a long way off if the federal bill is not enacted.

When I attempted to untangle the interstate aspects of the nofault autornobile insurance plans more than a year ago, recommending a drastic domicil-oriented solution, ${ }^{1} I$ was rushing to print with

* J.D. 1960, Cornell University; Professor of Law, College of Law, Ohio State University.

1. Kozyris, No-Fault Automobile Insurance and the Conflict of Laws-Cutting the Gordian Knot Home-Style, 1972 Duke L.J. 331. The solution proposed in this article was most basically stated in the form of a "golden rule": "to each according to his need, as determined by his state, and from each according to his obligation, as defined by his own state." Id. at 390 . Translated into practical effect, an enacting no-fault state would extend its first-party benefits, limited strict liability, and tort exemption only to its own doniciliaries, regardless of the place of the accident. Id. at 394. In the case of an accident involving domiciliaries of the enacting state and domiciliaries of another state, the claims of the latter parties would be relegated to their own laws, whether no-fault or liability, and would be net by the residual coverage of the enacting state's insurance policies; and their liabilities would also be determined under their own state's laws. The disparities between recovery and liability, if any, would be taken care of through the insurance mechanism. Id. at 397-98.

HEREINAFTER THE FOLIOWING CITATIONS WILL BE USED IN THIS ARTICLE:

Michigan Comp. Laws ANN. $\S \S 500.3101-179$ (1973-74 Supp.) (effective Oct. 1, 1973) (CCH AUTO. L. REP.-INs. If 1963 (Nov. 16, 1972) [hereinafter cited as Mich. No-Fault];

New Jersey Automobile Reparation Reform Act, N.J. STAT. ANN. \$§ 39:6A-1 to 6A-20 (Supp. 1973-74) (effective Jan. 1, 1973) (CCH AUTo. L. REP.-INs. II 1971 (Jan. 11, 1973)) [hereinafter cited as N.J. No-Fault];

New York Compreliensive Insurance Act, Insurance Law art. 18, ch. 13, Laws 1973 (effective Feb. 1, 1974) (CCH Auto. L. Rep.-Ins. If 1973 (Feb. 22, 1973)) 
the scholar's fear, and reformer's hope, that a federal uniform plan might very well be adopted within the year which would melt the problem away and make my contribution academic. Instead, the original federal plan lost momentum ${ }^{2}$ and its proponents reduced their sights to minimum federal no-fault standards. ${ }^{3}$ In the meantime state plans of diverse natures proliferated." "True" no-fault plans, mandating substantial insurance benefits and abolishing tort

[hereinafter cited as N.Y. No-Fault];

Kozyris, No-Fault Automobile Insurance and the Conflict of Laws-Cutting the Gordian Knot Home-Style, 1972 DUKE L.J. 331 [hereinafter cited as Kozyris].

National Conference of Commissioners on Uniform State Laws, UNIFORM MoTOR Vehicle Accident Reparations Act, Official Draft with Prefatory Notes and Comments (edition of Nov. 1, 1972) [hereinafter cited as UNIFORM ACT];

S. 354, 93d Cong., 1st Sess. (1973) (revised bill, reprinted in 119 Cong. REC. S. 15569 (daily ed. Aug. 3, 1973)) [hereinafter cited as Magnuson-Hart].

2. The Hart Bill, S. 945, 92d Cong., 1st Sess. (1971) (revised bill, reprinted in Hearings Before the Senate Comm. on Commerce, 92d Cong., 1st Sess., pt. 1, at 305-32 (1971) ) proposed a comprehensive federal no-fault plan which would have generally abolished tort liability of owners and drivers for personal injuries caused by the negligent operation of insured automobiles throughout the United States; and would have required all automobile owners to carry insurance covering the net economic loss of all injured persons, with the exception of occupants of other automobiles and persons engaged in criminal conduct. A substantially modified version of the Hart Bill, S. 945, 92d Cong., 2d Sess. (1972) (The National No-Fault Motor Vehicle Insurance Act), was referred on Aug. 8, 1972, by a $49-46$ vote of the Senate, to a "dead-end" study in the Senate Judiciary Committee, 118 Cong. REc., S. 13069-93 (daily ed. Aug. 8, 1972). See Magnuson, Nationwide No-Fault, 44 Miss. L.J. 132 (1973). See note 3 infra.

3. By the time S. 945 , supra note 2, was reported out of committee, its sponsors had abandoned their ambitious plans for a comprehensive national no-fault plan and had retreated to the more modest "minimum standards" approach-through which Congress merely establishes minimum nationwide standards, which the states must either equal or exceed in designing what is still their own no fault compensation scheme. Only in non-complying states does a federal Alternative Plan actually go into effect. See Magnuson, supra note 2, at 148.

On January 12, 1973, Senator Magnuson introduced in the Senate, for action by the 93d Congress, S. 354, which resembled S. 945 in all respects except that it now adopted the basic provisions and terminology of the Uniform Motor Vehicle Accident Reparations Act for the minimum standards and for the federal Alternative Plan which will go into effect in the non-complying states. 119 CoNG. REC. S. 518-35 (daily ed. Jan. 12, 1973). For further discussion of the Uniform Act, see note 23 infra and accompanying text. Lengthy hearings were held on S. 354 before the Senate Commerce Committee in the Spring of 1973. A similar piece of legislation was introduced in the House on February 7, 1973 by Representative Matsunaga, H. 4023, and was referred to the House Committee on Interstate and Foreign Commerce. 119 CoNG. REC. H. 872 (daily ed. Feb. 7, 1973).

On August 3, 1973, a revised version of S. 354 was reported to the Senate by Senators Magnuson, Hart and others. 119 Cong. REC. S. 15569 (daily ed. Aug. 3, 1973).

4. For a full collection of the texts of these plans, see CCH Auto. L. REP.-INs. ITT 1935-87B (1973). 
liability to some extent, were enacted (in addition to those previously in effect in Massachusetts and Florida ${ }^{5}$ ) in Colorado, ${ }^{6}$ Connecticut, $^{7}$ Hawaii, ${ }^{8}$ Kansas, ${ }^{9}$ Michigan, ${ }^{10}$ Nevada, ${ }^{11}$ New Jersey, ${ }^{12}$ New York, ${ }^{13}$ and Utah. ${ }^{14}$ No-fault features were also incorporated in the legislation of Arkansas, ${ }^{15}$ Maryland, ${ }^{16}$ Minnesota, ${ }^{17}$ Texas, $^{18}$ and Virginia, ${ }^{19}$ who thus joined Delaware, Illinois, Oregon, and South Dakota ${ }^{20}$ in the "hybrid" no-fault category. It has been reported that 42 percent of the population of the Umited States is presently under some kind of a nofault system and that pending legislation in ten more states, with a

5. Mass. ANN. LAws ch. 90, $\$ 34 \mathrm{~A}, \mathrm{D}, \mathrm{M}, \mathrm{N}$ (Supp. 1972); as amended by id. $\S 340$; FLa. Stat. ANN. \$ 627.736(1) (1972). See Kozyris at 380-83. The Florida Supreme Court, however, recently held that the Florida statute's abohtion of vehicular property damage recovery in tort was unconstitutional under the Florida constitution. K'luger v. White, 281 So. $2 d 1$ (Fla. 1973). The ruling did not consider the constitutionality of the other provisions of the Florida statute.

6. Colorado Auto Accident Reparations Act, Colo. Rev. STat. ANn. \$§ 13-25-1 to 13-25-22 (Supp. 1973) (effective April 1, 1974) (CCH Auro. L. REP.-INs. If 1946 (June 1, 1973) ). It is to be noted that the people of Colorado had previously rejected a no-fault plan by a decisive margin in a referendum held in Noveinber of 1972. See OhIo Trial 1 (Feb. 1973).

7. No-Fault Motor Vehicle Insurance Law, Conn. Laws 1972, P.A. No. 273 (May 19, 1972) (CCH AuTo. L. Rep.-Ins. II 1947 (July 14, 1972)) (effective Jan. 1, 1973).

8. Hawaii Motor Vehicle Reparations Act, H.B. No. 637, Laws 1973 (approved and effective May 31, 1973, for full inplementation on July 1, 1974) (CCH AUTo. L. REP.-INs. T 1952 (June 14, 1973)).

9. Kansas Automobile Reparations Act, Laws 1973, H.B. No. 1129 (Apr. 11, 1973) (CCH Auto. L. Rep.-Ins. If 1957 (Apr. 19, 1972)) (effective Jan. 1, 1974).

10. Mich. No-Fault.

11. Nevada Motor Vehicle Insurance Act, as amended by Laws 1973, ch. 530, $\S \S$ 2-51 (Apr. 24, 1973) (CCH AUTo. L. ReP.-INs. I 1969 (June 1, 1973)) (effective Feb. 1, 1974).

12. N.J. No-Fault.

13. N.Y. No-Fault. For a detailed discussion of the New York plan, see Comment, New York Adopts No.Fault: A Summary and Analysis, 37 ALB. L. REv. 662 (1973).

14. Utah Automobile No-Fault Insurance Act, Laws 1973, S.B. No. 112 (CCH AUTO. L. REP.-INS. Tl 1985 (Apr. 5, 1973) (effective Jan. 1, 1974).

15. Ark. Acts 1973, H.B. 158 (Feb. 16, 1973). (CCH Auro. L. ReP.INs. If 1944 (June 1, 1973)) (effective July 1, 1974).

16. MD. ANN. CODE art. 48A, $\$ 538-546$ (1972 Supp.) (effective Jan. 1, 1973) (CCH AUTO. L. REP.INS. T 1961 (Jun. 29, 1972)).

17. MINN. Stat. ANN. \$\$ 65B.01-.27 (1973 Supp.).

18. Tex. Ins. Code art. 5.06-3, added by. Laws 1973, H.B. No. 143 (Apr. 24, 1973) (CCH Auto. L. REP.-INs. II 1984 (May 3, 1973)).

19. VA. CODE ANN. $\$ \$ 38.1-380.1$ and 46.1-497.1 (1973 Supp.) (effective July 1, 1973) (CCH AUTO. L. REP.-INs. T 1987 (May 3, 1973)).

20. Del. Code Ann. tit. 21, § 2118 (Supp. 1972); Ill. Ann. Star. ch. 73, §§ 1065.150-163 (Smith-Hurd Supp. 1973); OrEGON Laws 1971, H.B. No. 1300; S.D. CoMP. LAws ANN. $\S \S 58-23-6$ to -23-8 (Supp. 1973). 
good chance of passage, would bring the figure up to 76 percent. $^{21}$ In other words, no-fault is spreading like wildfire. ${ }^{22}$

At its annual conference of August, 1972, the National Conference of Commissioners on Uniform State Laws approved a final draft of a Uniform Motor Vehicle Accident Reparations Act ${ }^{23}$ and recommended it for enactment in all states. The National Comınissioners stuck by their original plan, ${ }^{24}$ thus presenting a Uniform Act which coinbines abolition of tort liability for economic loss and most forms of general damages with comprehensive insurance coverage exceeding that in force in any of the presently enacted no-fault plans. $^{25}$ State legislation based on the Uniform Act is reported to be under consideration in Arizona, Kansas, and Minnesota. ${ }^{2 B}$ On the negative side, the American Bar Association, for the first time in history, squarely disapproved the Uniform Act and voted to "take immediate and greatly increased steps" to oppose state or federal nofault plans whicl imclude a tort exemption. ${ }^{27}$ In addition, the insurance industry, a substantial segment of which had been supporting strong no-fault, ${ }^{28}$ reached a compromise which is "far more conservative in all respects" than the Uniform Act. ${ }^{29}$

What is the portent of all this for the interstate problein? One thing is certaim now: even under the new Magnuson-Hart "national standards" bill, ${ }^{30}$ the possibility of conflicts will persist, smce each

21. Auto Reform in No-Fault Moves Ahead-76\% of U.S. Population Covered, Trial, vol. 9, no. 4 at 5 (Jul.-Aug. 1973).

22. For a recent symposium on no-fault, see Symposium, No Fault Automobile Insurance, 44 Miss. L.J. 1-181 (1973).

23. UNIFORM ACT. For a discussion of the Uniform Act, see, e.g., Hill, The Uniform Motor Vehicle Accident Reparations Act, THE ForUM, Vol. 8, 1972, at 1; Ghiardi \& Kircher, The Uniform Motor Vehicle Accident Reparations Act: An Anaiysis and Critique, 40 INs. CoMm. J. 87-110 (1973); Henderson, The Uniform Motor Vehicle Accident Reparations Act, 44 Miss. L.J. 107 (1973).

24. For a description of the original plan, see Kozyris at 377-80.

25. Only the Michigan plan is viewed as approximating the Uniform Act in scope of coverage. See 119 CoNG. Rec. S. 9507, 9508 (daily ed. May 22, 1973) (remarks of Senator Stevens).

26. National Conference of Commissioners on Uniform State Laws, Uniform Law Memo 2 (Spring 1973).

27. Id. at 1, 3. See also Meserve, President Meserve States American Bar Association Opposition to National No-Fault Insuranee Act, 59 A.B.A.J. 607 (1973).

28. See Kozyris 334 \& n.8.

29. National Conference of Commissioners on Uniform State Laws, Uniform Law Memo 2 (Spring 1973). It has been reported, however, that State Farm Mutual, the nation's largest auto imsurer, announced its support of the Magnuson-Hart minimum standards. N.Y. Times, Aug. 5, 1973, $\S 1$, at 15, col. 1.

30. See note 3 supra. 
state is given wide latitude in drafting its own plan, provided that, in its entirety, such plan meets or exceeds the minimum standards. ${ }^{31}$ What if Magnuson-Hart fails? Then the state patchwork is likely to continue with no assurance of nationwide acceptance of genuine no-fault, let alone minimum uniformity. In this eventuality, and given the fact that accidents involving out-of-state persons or cars are quite common, ${ }^{32}$ the conflicts complications will be at their zenith.

\section{Magnuson-Hart and Conflicts: A Step in the Right DiRection}

While the state plans are infused with strong dosages of territorialism, a major breakthrough towards a more sensible choice-oflaw approach has occurred at the national level. The latest version of Magnuson-Hart, which initially had incorporated the largely territorialist Uniform Act as a model for the states, ${ }^{33}$ has shifted decisively in the direction of the domiciliary contact, ${ }^{34}$ much along the lines proposed in my original article, at least within the nofault system.

Magnuson-Hart establishes minimum national standards which must be met by the states in order to avoid the imposition of a federal Alternative Plan. ${ }^{35}$ In the choice-of-law area, the principal features of the "minimum standards" state plans and of the federal alternative plan are the same.

First, car owners throughout the United States must provide

31. Magnuson-Hart, \& 202(b). See note 3 supra.

32. See Kozyris 341 n.28. See also U.S. Dep't of Transportation, I Automobile Personal Injury Clatms 10-11 (1970).

33. See note 3 supra and accompanying text.

34. Magnuson-Hart, especially $\S 110(\mathrm{c})$, which provides:

(c) APPLICABLE LAW.-(1) The basic restoration benefits available to any victim or to any survivor of a deceased victim shall be determined pursuant to the provisions of the State no-fault plan for motor vehicle insurance in accordance with title II or title III of this Act which is im effect in the State of domicile of the victim on the date when the motor vehicle accident resulting im imjury occurs. If there is no such State no-fault plan in effect or if the victim is not domiciled im any State, then basic restoration benefits available to any victim shall be determined pursuant to the provisions of the State no-fault plan for motor vehicle imsurance, if any, in effect in the State in which the accident resulting in injury occurs.

(2) The right of a victim or of a survivor of a deceased victim to sue in tort shall be determined by the law of the State of domicile of such victim. If a victim is not domiciled in a State, such right to sue shall be determmed by the law of the State in which the accident resulting in imjury or damage to property occurs.

It is the author's understanding that no changes to section 110 are presently contenplated by the Senate Commerce Committee, which has been leading the fight for national no-fault.

35. Id. $\S 201$. See note 3 supra. 
security under the plan in effect at the state of registration or operation of the car. ${ }^{36}$ This usually happens to be the state of their domicil or residence. ${ }^{37}$

Second, the qualifying insurance must (or is "construed" to) contain no-fault "coverage sufficient to satisfy the requirements for security covering a motor vehicle in any State in which any victim who is a claimant or whose survivors are claimants is domiciled or is injured."38 This sweeping provision is essential for the protection of insureds who becone involved in accidents in circumstances where no-fault benefits exceeding those required by the state of the insured are recoverable. "Victim" is defined to include all persons suffering "injury arising out of the inaintenance or use of a motor vehicle."39

Third, the insurance policies inust also contain $\$ 50,000$ coverage "to protect the owner or operator of a notor vehicle from tort liability to which he is exposed" in the "state of domicile of a victim" (or in the state of injury, if not domiciled in any state) but to which "lie would not have been exposed in the State of registration of the inotor vehicle." 40

Fourth, the no-fault benefits to all victims or survivors are determined under the plan in effect at the state of their domicil. If they are not domiciled in any state, then they recover under the law of the state of the accident. ${ }^{41}$

Fifth, the extent of the tort excinption available to the actor is to be "determined by the law of the State of dounicile of [the] victim," or, if not domiciled in any state, by the law of the state of the accident. ${ }^{42}$

36. Id. $\$ \S 104,202(\mathrm{a}), 301$.

37. Magnuson-Hart does not define "domicil." For a discussion of the ambiguitics caused by the interchangeable usage of the term8 "domicil" and "residence," see Kozyris $354 \mathrm{n} .89,392-93$. It would be wise, if not indispensable, for the bill to incorporate a clear, workable definition of "domicil" with particularized provisions, for example, for corporations, rental cars, students, etc. As for terminology, I would prefer "habitual residence" or "settled residence" over "domocil" as more indicative of the home connection. Id. In the present article, I use "domicil" and "home state" interchangeably to refer to the same kind of main link.

38. Magnuson-Hart $\S \S 110(b)(1), 202(a), 301$.

39. Id. \& 103(33).

40. Id. $\S \$ 110(\mathrm{~b})(2), 202(\mathrm{a}), 301$.

41. Id. $\$ \S 110(\mathrm{c})(1), 202(\mathrm{a}), 301$.

42. Id. $\$ \$ 110(\mathrm{c})(2), 202(\mathrm{a}), 301$. The language in section $110(\mathrm{c})(2)$ to the effect that "the right of a victim or of a survivor of a deceased victim to sue in tort shall be determined by the law of the State of domicile of such victim" could be broadly interpreted to establish a federal choice-of-law rule for tort claims for the negligent operation of automobiles in general. See also section $110(\mathrm{~b})(2)$ which requires 
Sixth, all victims, whether owners, operators, passengers or pedestrians, are entitled to no-fault benefits for accidents within the United States. ${ }^{43}$ For accidents in Puerto Rico, Canada, and Mexico, no-fault benefits are payable only to the insured, that is, the named insured and his resident family, and to the occupants of the insured car. ${ }^{44}$

Seventh, the victim recovers first from his own insurer, whereever and in whatever connection injured, and whether or not injured in or by his car. ${ }^{45}$ Considering that the owner and his resident family are covered under the owner's policy; that all car owners must carry such a policy; and that there are few people in the United States who neither own cars nor are resident ineinbers of a car-owning family, the federal plan goes a long way towards transforming automobile accident insurance from a third-party to a first-party compensation system. This will make it easier for insurance coinpames to measure their exposure and to calculate their premiums accordingly. ${ }^{40}$ With respect to the uninsured, they recover from the in-

the insurance policy to provide coverage protecting the owner from "tort liability to which he is exposed through application of the law of the State of domicile of a victim ... but to which he would not have been exposed through application of the law of the State of registration of the motor vehicle." It would appear, however, that such a far-reaching preemption of state tort choice-of-law practice was not intended, and this language should be understood to refer only to the application of the tort exemption within the context of the federal no-fault plan.

43. Id. \& 203(a), which provides:

(a) ACCIDENT WITHIN A STATE-If the accident resulting in injury occurs in a State in which a no-fault plan for motor vehicle insurance in accordance with this title or title III of this Act is in effect, any victim or any survivor of a deceased victim is entitled to receive basic restoration benefits.

44. Id. \& 203(b), which provides:

(b) ACCIDENT OUTSIDE ANY STATE.-If the accident resulting in injury occurs outside a State in which a no-fault plan is in effect, but in any other State, Puerto Rico, Canada, or Mexico, a victim or a survivor of a deceased victim is entitled to receive basic restoration benefits if such victim is or was-

(1) an insured; or

(2) the driver or other occupant of a secured vehicle.

The reasons for maintenance of a territorial, Keeton-O'Connell type approach for accidents outside the Umited States are not clear. It may be that section 203 has not as yet been redesigned to conform to the basic cliange of conflicts philosophy incorporated in section 110. See note 34 supra. Or, more probably, the retention of this approach may reflect a decision to use the pure domiciliary conflicts approach only within the no-fault system. In principle, this aberration of section 203(b)(2) for international conflicts is unfortunate, but it should be noted that it will be of only minor significance in practice.

45. Id. $\$ \$ 202(\mathrm{a}), 205(\mathrm{a})(2), 301$.

46. See the ingemious optional provision in Section 204(b)(1)(B) of the bill, to the effect that a named insured who, prior to the accident, voluntarily discloses to his insurer his actual monthly earned income and agrees that such sum shall measure work loss, is limited accordingly. 
surer or insurers of the cars involved ${ }^{47}$ or, as a last resort, from the assigned claims plan of their domicil, or, if not domiciled in any state, froin the plan of the accident state. ${ }^{48}$

The proposed federal bill adopts a choice of law approach which is clearly consistent with the coinpensatory aims of no-fault and with the grand design of spreading the losses through mandatory insurance. Its main thrust conforms to the "golden rule" enunciated in my original article ${ }^{48}$-it imposes insurance obligations on each car owner essentially under the law of his state and determines the reparation rights of each victim under the law of the victim's own hoine state. The use of the law of the place of the accident (lex loci delicti) as an auxiliary connecting factor for no-fault when a victim is not domiciled within a state in the United States, which in operation would be limited essentially to non-resident aliens, is quite appropriate, assuming a goal of expansive coverage for the nofault system and recognition of the accident state's secondary interest in the availability of sufficient reparations to the victims of traffic accidents.

In sum, with minor reservations as to particular details and language used in the federal plan, this writer wholeheartedly approves of its basic approach. The decision to make the choice of law turn on such specific connecting factors as, primarily, domicil, and secondarily, locus of the accident, is probably the only workable solution to a problem of such vast complexity as the interstate auto accident in the no-fault setting. Given the multiplicity of "significant" contacts likely to be invoked im such accidents, not to mention the variety of parties on behalf of whoin a "government interest" inight be advanced, reliance on the modern conflicts metlodologies ${ }^{50}$ to produce a suitable resolution in each case, or type of case, could lead only to further confusion. In light of sucl prospects, and in view of the visibility of the basic pohicies imvolved, ${ }^{51}$ resort to the more manageable rules adopted in Magnuson-Hart seems preferable to a quest for the "perfect," but elusive, ad hoc justice of the purists.

47. Magnuson-Hart $\S \S 202(a), 205(a)(3)-(4), 301$.

48. Id. \$§ 108(a)(1), 202(a), 205(a)(5), 301 .

49. See note 1 supra.

50. The "governmental interests analysis" of Brainerd Currie, the "primciples of preference" of David Cavers, and the "most significant relationship" test of the Restatement (SeCOND) OF CoNflict or Laws (1971) are perhaps the most imfluential of the modern conflicts methodologies and are discussed in Kozyris 348-52.

51. I.e., compensating mjured persons as efficiently and equitably as possible, without any reference to culpability, by spreading losses among the general motoring public. 


\section{The Uniform Act and the State Plans}

Given the relatively progressive nature of the federal bill, it is disappointing that the final version of the Uniform Act did not significantly depart from the essentially territorialist choice of law approach of the earlier draft. ${ }^{52}$ Thus, while the present Uniform Act does provide coverage for the insured, his resident relatives, and occupants of the insured car even when they are involved in out-of-state accidents, ${ }^{53}$ the Act's partial tort exemption still stops at the state line. ${ }^{54}$ All persons imjured in-state are entitled to no-fault benefits and all persons injured out-of-state, other than those mentioned above, are excluded. Only the uninsured owner is excluded from the tort exemption for in-state accidents. ${ }^{55}$ The domicil or residence of the victim as such is essentially of no consequence.

It is the author's understanding that certain draftsmen of the choice of law provisions of the Uniform Act, who were not convinced of the soundness of the domiciliary approach in the context of the Act, were nonetheless influential in moving the federal plan in the domiciliary direction. This inconsistency apparently does not reflect a change of heart, but rather a reconsideration of the suitability of the territorial approach in a setting where minimum nofault standards are imposed nationwide. When tort liability disappears (at least up to a given damage threshold) and when differences as to recoverable benefits among the state plans are reduced, the conflicts become less acute, and the balance of argument shifts in favor of the personal over the territorial contact.

If the federal plan is not eventually enacted, and in view of the very limited success of the Uniform Act, the odds are in favor of a continuation of the state-by-state, crazy-quilt pattern of conflicting accident reparation provisions.

A review of the present state plans in the context of their interstate application reinforces the prediction in my original article that territorialism would continue to play a major role, particularly for the tort exemption. At the same time, the categories of persons entitled to first-party type insurance benefits have generally been broadly defined, which has the practical effect of bringing the bulk of such persons within the plan of their domicil or residence.

52. See Kozyris $377-80$.

53. UNIFORM ACT $\$ \S 1(a)(3), 2(b)$.

54. Id. $\S 5$.

55. Id. $\S \S 2(\mathrm{a}), 5$. 
Rather than summarize and compare the interstate features of the new state no-fault plans in abstracto or in tabular form, it would be more interesting and instructive to explain how they work in particular situations. Since both Michigan and New York have joined the no-fault movement, it would be intriguing to start with a hypothetical along the basic pattern of the famous case of Tooker v. Lopez, advancing the date ten years to 1974 .

\section{The Tooker v. Lopez HypotheTICAL}

The Tooker scenario is rather simple: Miss Tooker and Miss Lopez, Michigan coeds but New York domiciliaries, were killed in a one-car accident in Michigan, Miss Lopez at the wheel. Another passenger, Miss Silk, a Michigan girl, was injured. The car belonged to Miss Lopez' father, a New York domiciliary, and had been registered and insured in New York. Miss Tooker's father sued in New York for wrongful death, and the Court of Appeals ultimately applied New York law in rejecting the Lopez defense based on the Michigan guest statute. In rejecting the lex loci in favor of the domiciliary law, the court concluded that there was no Michigan policy or interest which would be vindicated by the application of the Michigan guest statute to ban the Tooker claim. In the absence of a competing state interest, the court felt free to apply New York law to determine the rights and responsibilities of its domiciliaries. ${ }^{\text {.7 }}$

With the poetic hicense freely available to conflicts writers, and for the specific purpose of complicating matters in order to test the outer limits of the plans, let these facts be changed in the following ways. First, all three girls survived but were only shightly injured. Second, the crash involved a collision with an uninsured car registered in Ohio, driven by an Ohio domiciliary who was also shightly injured. Ohio has no mandatory insurance requirement. Third, the accident also injured an innocent pedestrian from New Jersey (which recently enacted a no-fault plan) ${ }^{58}$ who was visiting Ann Arbor as a tourist and who liad car owner's insurance in New Jersey. Fourth, only Miss Lopez was negligent. Fifth, the Lopez car was directly owned and registered by Miss Lopez rather than ler father. And sixth, Miss Lopez and Miss Tooker were only passing through Michigan to pick up their Michigan friend, Miss Silk, during a planned vacation trip to California.

56. 24 N.Y.2d 569, 249 N.E.2d 394, 301 N.Y.S.2d 519 (1969).

57. Id. at 576,249 N.E.2d at 398,301 N.Y.S.2d at 528 .

58. See note 12 supra. 
To put the question in the classical law-school-exam fashion: What are the rights of the parties? Or better: What is the effect of the various state no-fault plans involved upon the rights of the parties?

Tort and Other Liability. It is clear that the tort liability of the hypothetical Miss Tooker toward all the potential claimants remains unaffected by the Michigan, New Jersey, and New York plans. In Michigan, the tort exemption applies to in-state accidents but only if the car is insured under the Michigan plan. ${ }^{59}$ The New Jersey and New York tort exemptions apply only to in-state accidents. ${ }^{60}$ Thus, in a situation where a driver from a no-fault state has an accident in another no-fault state, injuring a party from yet another no-fault state, we are left with the questionable result of no applicable tort exemption.

It is interesting to observe that had the Ohioan had an imjured passenger and had his car been in Michigan for more than thirty days in the same calendar year, he would have been personally liable under the Michigan plan to pay Michigan-type no-fault benefits to his passenger on a strict liability basis. ${ }^{61}$ The same would have been true for Miss Lopez with respect to Miss Tooker and Miss Silk had Miss Lopez satisfied the thirty-day test, regardless of neghigence. In that situation, would her New York insurance policy have covered her? New York has carried its territorialism to the point of requiring New York policies to carry residual insurance coverage to comply with the mandatory insurance provisions of the state where the car is driven. ${ }^{62}$ This attempt to fix the insured's out-of-state obligations in accordance with the law of the place of the accident could pro-

59. See Mich. No-Fault \$\$ 3135(2), 3101(3)-(4). It should be pointed out, however, that if the New York insurer of Miss Lopez happened to have been authorized to transact business in Michigan and had filed a required special certificate in Michigan, the New York policy would have included Michigan coverage, id. $\$ 3163$, in which case the partial Michigan tort exemption would have been applicable.

60. N.J. No-Fault \& 8; N.Y. No-Fault $\$ 673(1)$.

61. Micli. No-Fault $\S \S 3102,3177$.

62. N.Y. No-Fault $\S 672(5)$. Michigan also follows this approacli. See Mich. No-Fault $\S 3131$.

In Comment, supra note 13, at 679 (1973), the New York provision is explained as follows: "When a vehicle insured in New York is driven in another state or Canadian province, the rights of New York motorists are generally determined under the laws of the particular place in which the motorist is driving." See also UNIFORM ACT $\$ 5$, Comments, at p.26:

This Section limits the application of the geueral tort exemption to liability arising froin inotor vehicle accidents within the state. The victim of an out-of-state automobile accident would be entitled to whatever tort remedy is allowed him by the state where the accident occurred. . . 
duce paradoxical results in situations where a court applies one of the modern conflicts methodologies, such as government interest analysis, to impose hability under the laws of a state in which the insured was not driving at the time of the accident. Such an eventuality could conceivably leave the New York insured without coverage, since his policy technically need only comply with the mandatory provisions of states where the car is driven at the time of the accident. If Miss Lopez had been in-state for thirty days, however, the Michigan plan would have required the exaction of no-fault reparations in accordance with the Michigan requirenents. And since Miss Lopez was driving in Michigan when the accident occurred, the payments would probably come within the New York insurance coverage under the residual liability clause. ${ }^{63}$

Returning to the basic hypothetical of Miss Lopez' negligence, the outcome with respect to the tort claim of Miss Tooker (a guest of Miss Lopez domiciled in New York) would depend on whether the action is brought in Michigan or in New York. Since Michigan follows basically the lex loci delicti rule, ${ }^{64}$ the Tooker claim would be barred under the Michigan guest statute ${ }^{65}$ in Michigan; whereas it would be allowed in New York under New York law, which has no guest statute and which would be applicable pursuant to the actual Tooker decision. ${ }^{\circ 6}$ As to the claim of Miss Silk (a guest of Miss Lopez domiciled in Michigan) it would be barred under Michigan law even if the action were brought in New York, in accordance with the deviation from Tooker elaborated in Neumeier v. Kuehner. ${ }^{67}$ In that case, the New York Court of Appeals held that it would enforce a foreign guest statute to bar recovery in behalf of a domiciliary of the foreign jurisdiction killed in an automobile accident in that jurisdiction while the guest of a New York domiciliary. The court distinguished Tooker by reasoning that New York had no interest in protecting a foreign domiciliary from limitations on his right to recovery imposed by his own jurisdiction. ${ }^{68}$

No-Fault Benefits. The no-fault benefits allocable to the various parties according to the laws of the states connected with the hypothetical are as follows:

63. See Comment, supra note 13, at 680.

64. See Abendschein v. Farrell, 382 Mich. 510, 170 N.W.2d 137 (1969).

65. Mich. Stat. Ann. \$ 9.2101 (1968).

66. See text accompanying note 57 supra.

67. 31 N.Y.2d 121, 286 N.E.2d 454, 335 N.Y.S.2d 64 (1972).

68. Id. at 125,286 N.E.2d at 456,335 N.Y.S.2d at 68. 
(a) Miss Tooker:

(i) None under the New York plan, since the accident took place out-of-state. ${ }^{09}$

(ii) None under the Michigan plan, since she was not herself insured under the Michigan plan or a residing relative of an insured and because she, a non-resident, was injured in a car of outof-state registration which had not qualified for Michigan insurance coverage. ${ }^{\mathbf{7 0}}$

(b) Miss Lopez:

None under either the New York or Michigan plans for at least the same reasons as Miss Tooker.

(c) Miss Silk: as Miss Tooker.

(i) None under the New York plan, for the same reasons

(ii) Yes, under the Michigan plan, since she was a Michigan resident and an occupant of a car which had an in-state accident, ${ }^{71}$ even if she were not herself insured or a residing relative of an insured. Recovery would be froin the Michigan assigned claims plan. ${ }^{72}$

(d) The Ohioan:

None under the New York or Michigan plans for at least the same reasons as Miss Tooker.

(e) The New Jersean:

(i) None under the New York plan, for the same reason as Miss Tooker.

(ii) Yes, under the New Jersey plan, since he was insured under a New Jersey policy which extends coverage to the insured injured as a pedestrian by any automobile out-of-state. ${ }^{73}$

(iii) Yes, under the Michigan plan, ${ }^{74}$ which extends coverage to non-resident pedestrians injured in-state. Since no Michigan insurance pohicy is apphicable to his claim, his recovery would be froin the assigned claims plan. ${ }^{75}$ In substance, therefore, the New Jersean would have a choice between the New Jersey and the Michigan plans. If the New Jersean then proceeded to recover in tort

69. N.Y. No-Fault \& 672(1).

70. Mich. No-Fault $\$ 3113(c)$. The opposite result would follow, however, if Miss Lopez' insurer had filed a Michigan insurance certificate. See note 59 supra.

71. Id. $\$ \$ 3113(\mathrm{c}), 3114(4)$.

72. 1 d. $\S 3172$.

73. N.J. No-Fault $\$ 4$.

74. Mich. No-Fault § 3115 .

75. $I d$. $\& 3172$. 
from Miss Lopez, however, he would be required to reimburse the paying insurer up to the amount of the no-fault benefits received.

This summary of the no-fault benefits actually generated by the statutes in effect in the home states of the parties involved reveals an ironic outcome coniparable to that which was observed under the tort exemption: with three no-fault statutes in effect (New York, Michigan, and New Jersey) from which to allocate reparations, three of the five imjured parties would receive no no-fault benefits. Had the New York plan been domiciliary-based in its recovery provisions, however, or had it even made benefits for the imsured and the occupants of his car portable extraterritorially (as does the Michigan plan), ${ }^{76}$ only the uninsured Ohioan would have been without coverage.

\section{Transposing the Tooker v. Lopez AcCIDENT to NeW York}

For a better illustration of the workings of the New York plan, it would be worthwhile to transpose the accident to New York and reverse the domicil factor for Miss Tooker, Miss Lopez, and Miss Silk, so that the former two are Michigan domiciliaries and the latter a New York domiciliary and the Lopez car is registered and insured in Michigan. All other facts remain the same.

Tort and Other Liability. If the insurer of the Michigan domiciliary (Miss Lopez), or its parent, subsidiary, or affiliate are authorized to transact business in New York, the New York plan would forcibly engraft its own no-fault features upon the out-of-state insurance when the car is driven in New York. ${ }^{77}$ Consequently, the Michigan domiciliary would be shielded by the substantial New York tort exemption ${ }^{78}$ with respect to the claims of all parties other than

76. Id. $\$ 3111$. See text accompanying note 95 infra.

77. N.Y. No-Fault $\S 676$. The originally proposed New York plans had gone further by engrafting a New York no-fault clause on all out-of-state insurance policies for the period that the insured car was driven in-state, regardless of whether the insured and the insurer had any other contacts with New York. See Kozyris 367-68, 373. This approach is still used in the Uniform Act. UNIForm Acr \& 9(b). The author had expressed some doubt as to the constitutionality of this kind of a provision, see Kozyris 378, and the New York plan subsequently dropped it-principally on the basis of a memorandum prepared by former Chief Judge Desmond of the New York Court of Appeals which raised questions as to the validity of the provision under the interstate commerce and contract clauses of the United States Constitution. Sce Ghiardi \& Kircher, supra note 23, at $94-95$ (1973). See also Note, No-Fault Motor Vehicle Insurance: A Constitutional Perspective, 46 ST. Johs's L. REv. 104, 121-24 (1971).

78. N.Y. No-Fault $§ 673(1)$. 
the Ohioan. ${ }^{79}$ If the insurer lacked such contacts with New York, however, the Michigan domiciliary would not be entitled to the tort exemption at all.

As to the non-neghigent uninsured Ohioan, he would not be subject to the New York insurance requirement in these circumstances, he would not be entitled to no-fault benefits, ${ }^{80}$ and he would not be protected by the tort exemption-because he is not a "covered person" under the plan. ${ }^{81}$ In this respect, the actual New York plan is significantly less territorial than the original Stewart and Gordon plans proposed for New York, which would have completely subjected out-of-state motorists driving in New York to the New York no-fault system. ${ }^{82}$

The Michigan tort exemption would not be available to the Michigan domiciliary driving in New York, simce it applies only to instate accidents, ${ }^{83}$ and the same is true, inter alia, of the New Jersey exemption. ${ }^{84}$ The Ohioan, of course, is not entitled to any Michigan or New Jersey tort exemption for this and other reasons.

No-Fault Benefits. The no-fault benefits payable under the various plans in the transposed New York accident are as follows:

(a) Miss Tooker (here a Michigan domiciliary)

(i) Yes, under the New York plan, from Miss Lopez' insurer, assuming that the latter, or an affihate or subsidiary, is authorized to do busmess in New York. ${ }^{85}$

(ii) Yes, under the Michigan plan, as an occupant of a Michigan insured car. ${ }^{86}$

(iii) None under the New Jersey plan. ${ }^{87}$

(b) Miss Lopez (here a Michigan domiciliary)

Same as Miss Tooker.

(c) Miss Silk (here a Michigan domiciliary)

Same as Miss Tooker.

79. Id. $\$ \$ 671(10), 673(1)$. Under these sections, the tort exemption extends only to recoveries by "covered" persons against other "covered" persons, and the Ohioan is not a "covered" person.

80. Id. $\S 672(1)(a)$.

81. Id. $\S 673(1)$.

82. See Kozyris $368 \&$ \&.134; 372 \& n.153.

83. Mich. No-Fault \& 3135(2).

84. N.J. No-Fault $\S 8$.

85. N.Y. No-Fault $\$ 672(1)(a), 676$.

86. Mich. No-Fault $\S 3111$. See text accompanying note 95 infra.

87. N.J. No-Fault $\$ 4$. 
(d) The Ohioan uninsured car. ${ }^{88}$

(i) None under the New York plan as an occupant of an

(ii) None under the Michigan plan for the same reason. ${ }^{80}$

(e) The New Jersean

(i) Yes, under the New York plan, from Miss Lopez' insurer, ${ }^{00}$ assuming again that the policy is made subject to the New York plan. out-of-state. ${ }^{91}$

(ii) None under the Michigan plan, as a pedestrian injured

(iii) Yes, under the New Jersey plan, as a named insured of a New Jersey policy. ${ }^{02}$

\section{Outcome Analysis Under the State Plans}

Does this allocation of rights and responsibilites in both the Michigan and the New York accident hypotheticals do "conflicts justice," and is it consistent with the purpose and policies reflected in the no-fault concept?

Assuming that no-fault aims at compensation rather than deterrence or retribution, ${ }^{03}$ and that the "interest" of the state of the accident as such is limited to insuring that there will be adequate provision for the expenses incidental to the accident (mostly the medicals), ${ }^{04}$ certain results reached in the hypotheticals are less than satisfactory.

First, since both Michigan and New York espouse the no-fault approach, including the tort exemption, what purpose is served by preserving for Miss Tooker the option to pursue the tort route against Miss Lopez under the law of either state merely because the insurer of Miss Lopez did not happen to transact business in such state? All the contacts of Miss Tooker and Miss Lopez, including domicil, car registration and insurance, accident location, etc., depending on the hypothetical, are with a no-fault state. Is it not true that the reduction of litigation is one of the main aims of no-fault? Is this not a case of falling between two stools?

88. N.Y. No-Fault $\S 672(1)(a)$.

89. Mich. No-Fault $\S \S 3111,3113(c)$.

90. N.Y. No-Fault $\$ 672(1)$ (a).

91. Mich. No-Fault § 3111.

92. N.J. No-Fault $\$ 4$.

93. See Kozyris 338-39.

94. Id. at $358 \mathrm{n} .95,391$. 
Second, in the Michigan accident, why should New York exclude its domiciliaries, Tooker and Lopez, injured in a car registered and insured under no-fault in New York, from its benefits? In this type of situation, the actual Tooker case clearly called for the application of New York law. Michigan, and nost states, follow the correct rule of making such benefits portable extraterritorially in most instances. $^{.55}$

The same questions may be raised with respect to all accidents (including collisions) occurring out of state, where the cars and persons involved came froin the same state or froin states with the same type of compensation system.

Third, in the New York accident, what is the reason for New York applying its own no-fault law to measure, for example, the lost earnings of the two Michigan girls ${ }^{98}$ rather than referring to the Michigan measure? ${ }^{27}$ Since the injuries here were slight (as is the case in most instances where the no-fault plan inakes the difference), one would expect the girls to return to their home base. Why should their earnings loss be calculated under New York standards? This approach is particularly objectionable when one considers that it is the Michigan insurer under a Michigan policy who would be required to pay these amounts under the New York "transformation" clause. ${ }^{88}$ The same criticism inay be applied to the operation of the Michigan plan in the Michigan accident hypothetical, where the out-of-state insurer wlo has filed a certificate subjects itself to the Michigan coverage requirements.

Fourth, why, in either case, where insurance coverage is avail-

95. Colorado Auto Accident Reparations Act, Colo. Rev. Stat. ANn. \$\$ 13-25-1 - 13-25-22 (Supp. 1973); Connecticut No-Fault Motor Vehicle Insurance Law, Conn. Laws 1972, P.A. No. 273 (May 19, 1972) (CCH AUto. L. ReP.-Ins. II 1947 (July 14, 1972)); FLA. Stat. ANN. \$ 627.736(4)(d)(2) (1973); Hawaii Motor Vehicle Reparations Act, Laws 1973, H.B. No. 637, \& 3(b)(1) (CCH Auto L. ReP.-INs. If 1952 (June 14, 1973)); Kansas Automobile Reparations Act, Laws 1973, H.B. No. 1129, § 9(a) (Apr. 11, 1973) (CCH AUto L. ReP.-Ins. II 1957 (Apr. 19, 1973)); Mass. ANn. Laws ch. 90, § 34(a) (1971); Mich. No-Fault § 3111; Nevada Motor Vehicle Insurance Act, Laws 1973, ch. 530, \& 24 (Apr. 24, 1973) (CCH Auto. L. REP.-INs. If 1969 (June 1, 1973)); N.J. No-Fault $\S 4$.

Only Utah joins New York in limiting no-fault benefits to in-state accidents. Utah Automobile Insurance Act, Laws 1973, S.B. No. 112 (CCH AUTo L. REP.-INs. If 1985 (Apr. 5, 1973)).

96. Under the New York act, the lost earnings would be up to $\$ 1,000$ per month for 3 years, less $20 \%$. N.Y. No-Fault $\$ 671(1)$ (b), 2(a).

97. In this case, the Michigan measure is virtually identical. Mich. No-Fault § 3107(b).

98. N.Y. No-Fault $§ 676$. 
able, should the tort exemption be calculated under the plan of the accident state rather than that of the state of the most important contacts, such as common domicil, car registration and insurance, trip origination, etc.?

It is interesting to note that as a result of the territoriality of the New York plan, in the Michigan accident hypothetical with insurance present, the New York courts will find themselves in the peculiar position of first applying the Michigan plan to determine no-fault benefits and tort exemption; and then probably returning to the New York tort law under the actual Tooker decision to determine the inain claims of the New York domiciliaries.

Fifth, why should the New Jersean be entitled, for exainple, to earnings loss benefits pursuant to the Michigan and New York plans inerely because the accident took place within the borders of those states, especially since he was insured under a New Jersey policy providing for New Jersey-type benefits?

Under the domicihary approach proposed in my original article, all of these problems would disappear. ${ }^{90}$ Whatever the locus of the

99. It is noteworthy that some of the state no-fault plans take the victim's residence specifically into account in certain limited instances in making the determination of whether no-fault benefits are payable or whether there is an insurance obligation. See, e.g.:

Connecticut: Section 9(a) of the Connecticut No-Fault Motor Vehicle Insurance Law distinguishes between residents and non-residents with respect to the insurance obligation.

Kansas: In the Kansas Automobile Reparations Act, sections 5(f), 6, and 7 exempt non-residents from insurance obligations in certain instances; section 9(a)(4) states that only residents are entitled to benefits as injured pedestrians in-state, and section 16 makes the assigned claims plan available only to residents.

Massachusetts: Under MAss. ANN. LAws ch. 90, $\$ 34 A$ (1971), resident pedestrians are entitled to benefits for out-of-state injuries inflicted by an insured car.

Michigan: Mich. No-Fault $\$ 3102$ (Special provisions on insurance by nonresidents); $\$ 3113$ (c) (non-residents occupying out-of-state, uninsured cars not entitled to no-fault benefits for in-state injuries).

Nevada: Nevada Motor Vehicle Insurance Act, $\$ 24(2)$ (non-residents injured out-of-state in secured commercial vehicle not entitled to benefits).

Utah: Utah Automobile No-Fault Insurance Act, $\$ 4$ (distinguishing between residents and non-residents with respect to the insurance obligation).

Professor Pearson, one of the very few to make some comment on the interstate aspects of no-fault, appears to favor extending benefits to residents and excluding non-residents whatever the place of the accident, at least if the main thrust of no-fault is to provide compensation for the victims. But he assumes that the tort exemption is to be territorial. Pearson, Implementing the No-Fault Concept: An Analysis of Some Alternatives, 44 Miss. L.J. 74, 79-81 (1973).

A recent case decided in Rhode Island, which follows the government interests approach to the clioice of law, articulates quite clearly the relevance of the residence 
accident, all injured persons would recover under the law of their hoine state, and no person causing injuries would carry a reparation burden heavier than that imposed by his own home state. ${ }^{100}$

While it is true that the no-fault insurers may thus be required in soine circuunstances to pay benefits or damages to an injured nondomiciliary in excess of the amounts recoverable under the law of the no-fault state, this is neither unusual nor oppressive, at least when viewed from the perspective of the insurance imdustry of the no-fault state as a whole. It is not unusual because this possibility is also present in a lex loci system, since the accident may occur in a state whose laws provide for greater recovery than the law of the state of insurance. It is not oppressive because the benefits or damages payable on a domiciliary principle im any given case could well be below those available under the law of the no-fault state. Accordingly, the total insurance impact resulting from the use of the domiciliary approach is likely to be negligible in the long run. ${ }^{101}$

\section{EARLIER INFLUENCES AND CONTINUING CONCERNS}

Both before and since the publication of my original article, I have been unable to discover a comprehensive articulation of the rationale behind the choice-of-law rules of the various state no-fault plans, including the Uniform Act. ${ }^{102}$ Nonetheless, several factors affecting the evolution of the current no-fault statutes at least partially explain their territorialist orientation. The decisive influence of the Keeton-O'Connell plan, which limited the tort exemption to in-state accidents and narrowly defined the classes of persons entitled to benefits for out-of-state accidents; the appeal which the familiarity and predictability of the traditional lex loci rule must have had for the practical-minded tort and insurance experts who were the principal draftsmen of the no-fault plans; and the general preoccupation with the substantive aspects of no-fault in the drafting of the plans

connection for automobile accidents. Labree v. Major, 306 A.2d 808, 817-18 (R.I. 1973).

Another interesting example of the increasing reliance on the domiciliary factor is found in the Draft Convention on the Law Applicable to Contractual and Non-Contractual Obligations of the European Economic Community. Even in as traditional a field as contracts, the Draft Convention in article 4(2)(a), adopts a basic choice principle in favor of the law of the habitual residence of the party who is to perforn the main obligation. See Documents, 21 AM. J. CoMP. L. 587, 588 (1973).

100. Kozyris 390-91. This assumes, of course, that the home-state no-fault plan includes a residual coverage clause in its qualifying insurance policies.

101. For a fuller explanation of this point, see Kozyris 398-400.

102. See id. at 374-75, 380. 
apparently left little room for in-depth consideration of complex choice-of-law alternatives. Consequently, a territorialist solution to the choice-of-law problems may have evolved more by default than as the result of any conscious process of deliberation.

In explaining this adherence to the lex loci rule, one should also not underestimate the effect of the lack of a workable, comprehensive choice-of-law theory as an alternative. Modern conflicts theory lias not as yet produced a satisfactory new system of the kind that would appeal to legislators ${ }^{103}$ and it must be conceded that a new territorialism is regaining favor in certain contexts. ${ }^{104}$ A tempting possibility in the drafting of the no-fault plans would have been to finesse the choice-of-law issue, much along the lines of the Uniform Commercial Code, ${ }^{105}$ and make the no-fault benefits or tort exemption available to persons liaving an "appropriate relation to the state," leaving the task of the particular choices to the judiciary. But such a "solution" would have done little more than add confusion and uncertainty to an already complex subject.

In order to understand the Keeton-O'Connell choice-of-law approach, and its influence on many of the state plans, it is important to keep in mind that the Keeton-O'Connell plan imvolves a cross between first-party insurance and strict habihty primciples and that it is limited in coverage and application. Had it been based solely on first-party insurance principles coupled with the abolition of tort hability, the victims recovering solely from their own insurers, the choice-of-law issue would have virtually disappeared. The extent and nature of benefits would have depended on the terms of the policy and the pohicy would have been issued, as a practical matter in almost all the cases, in and under the law of the insured's lione state, ${ }^{106}$ where the car is generally required to be registered. It is the strict liability aspect of no-fault, the imposition of obligations on car owners and possibly drivers for the benefit of others, that causes the main conflicts problem. Since the Keeton-O'Connel plan had been prepared when the lex loci delicti was prevalent, at least in practice, and since it was limited in that it did not replace the tort

103. Cf. id. at 347-52.

104. See, e.g., Sedler, The Territorial Imperative: Automobile Accidents and the Importance of a State Line, 9 DUQUESNE L. REv. 394 (1971); Twerski, Enlightened Territorialism and Professor Cavers, 9 DuQUesNe L. Rev. 373 (1971); Twerski, Neumeier v. Kuehner: Where Are the Emperor's Clothes?, 1 HofsTRA L. REv. 104 (1973); Twerski, To Where Does One Attach the Horses?, 61 KY. L.J. 393 (1973). 105. UNIFORM COMMERCIAI CODE, § 1-105.

106. See Kozyris 337 n.21. 
system entirely, it was natural that it responded to the territorial imperative. The plan's only significant deviation from rigid territorialism was its concession of benefits to the insureds and occupants of the insured car even in out-of-state accidents-following in this respect the pattern of medical benefits in the traditional liability insurance policy. ${ }^{107}$

Keeton and $O^{\prime}$ Connell were also somewhat concerned with the constitutional permissibility of full-blown extraterritoriality for the tort exemption-as well as with the possibility of imconsistent results that might ensue if other states refused to give effect to that exemption. ${ }^{108}$ Although it may be true that a second interested state would not be required by the full faith and credit clause to give effect to an extraterritorial tort exemption granted by the enacting state, there is no constitutional restriction upon the state's power to enact a domiciliary-based tort exemption with the expectation that other states will recognize it in most instances. The validity of the domiciliary contact as a state interest sufficient to justify choice-oflaw formulations is now well established. ${ }^{109}$ And while the objective of uniformity of result at all potential forums remains desirable, it is not conclusive. ${ }^{110}$ In any event, the dimensions of expected inconsistency are reduced in view of the abandonment of the lex loci delicti by many important jurisdictions. ${ }^{111}$ Furthermore, since the type of no-fault plan proposed in my earlier article $\mathrm{e}^{112}$ would provide medical benefits for all the domicilaries of the enacting state, whereever the accident; would not impose liabilities on the out-of-staters beyond those of their own state; and would allow injured out-ofstaters to recover under their own law, there would be no major reason why its extraterritoriality should not be recognized.

As to the im-state applicability of the no-fault system, it has been pointed out to me that my proposed plan would subject the domiciliaries of the enacting state as defendants to the inefficiencies of the tort system if an injured party happens to be an out-of-stater from a jurisdiction retaining tort liability. While this is true, it is at least counterbalanced by the expected reduction of litigation among

107. Cf. UNIFORM ACT $\$ 2$, Comment.

108. Kozyris 375 n.162.

109. See, e.g., Neumeier v. Kuehner, 31 N.Y.2d 121, 335 N.Y.S.2d 64 (Ct. App. 1972) and Rosenthal v. Warren, 475 F.2d 438 (2d Cir. 1973), discussed in text. accompanying notes 119-126 infra. See generally Kozyris 403 n.262.

110. See Restatement (SeCOND) of Conflict of LaWs \& 6 (1971).

111. See Kozyris 347 n.63.

112. See note 1 supra. 
no-fault domiciliaries involved in out-of-state accidents. In exceptional situations, however, and especially if the reduction of litigation is viewed as the paramount consideration, it may be wise to bend the domiciliary principle by limiting the out-of-stater's recovery for instate accidents to the no-fault benefits of the no-fault state. Such an adjustment would seem appropriate in a jurisdiction such as the District of Columbia, where a substantial percentage of cars and persons are from another jurisdiction.

Soine doubt has also been expressed on the use of domicil or residence as the connecting factor at a time when our population has become more inobile and the home connection more tenuousand when discrimination based on residence has come under constitutional attack on equal protection and privileges-and-immunities grounds. In the treatment of no-fault as a state problem, however, the assuniption is implicit that regional differences justify different approaches. The issue, then, is not whether wa should have uniformity or diversity; the issue is low the diverse plans may be so designed as to mesh together on the interstate plane. In this context, it would seem that the law of the place where one lives and where he normally registers, garages, and msures his car is preferable to the law of the place where the accident happens. ${ }^{113}$

\section{Some Constitutional Considerations}

As indicated earlier, the power of the states to enact and enforce no-fault provisions which tie compensation and tort exemption benefits to a person's domicil does not appear vulnerable to successful attack on constitutional grounds. To be sure, the Supreme Court has recently struck down state "durational" residence requirements in certain contexts. Such requirements have succumbed to attack on the basis of equal protection, due process, and/or the right to travel, when applied as a precondition to welfare benefits (Shapiro v. Thompson), ${ }^{114}$ voting rights (Dunn v. Blumstein), ${ }^{115}$ and standard tuition charges (Vlandis $v$. Kline).${ }^{116}$ A study of the opmions in these cases, lowever, is quite reassuring for the continued viability of the domiciliary connecting factor in choice-of-law. First, in all of these cases, there was discrimination among various categories of residents, not between residents and non-residents. As a matter

113. See Kózyris 354-55.

114. 394 U.S.S. 618 (1969).

115. 405 U.S. 330 (1972).

116. 41 U.S.L.W. 4796 (U.S. Jụne 11, 1973). 
of fact, in Vlandis, the right of a state to charge higher tuition to non-residents was not challenged since this issue had already been decided affirmatively in Starns v. Malkerson. ${ }^{117}$ Second, these cases involved allegedly "invidious" discrimination, the denial of rights or benefits to certain groups on a basis which was either irrational or not grounded on a coinpelling state interest.

The decision to nnake the choice of law in the no-fault context on the basis of doinicil or residence is not "invidiously" discriminatory, since it reflects a neutral principle of allocation which may be favorable or unfavorable to the non-domiciliary or non-resident depending on the content of the applicable law. It extends the obligations, as well as the benefits, of the state no-fault plan to the domiciliary class. Moreover, the state interest in its residents or domiciliaries is well recognized, ${ }^{118}$ so that enploying this connecting factor is not arbitrary or irrational.

Two recent and leading New York cases illustrate well the viability, as well as the constitutional validity, of the domicilary contact as a basis for the choice of law. In both Neumeier v. Kueh$n^{110}$ and Rosenthal $v$. Warren, ${ }^{120}$ the domicil of the plaintiff was the crucial factor in determining whether New York substantive law would be applied. In both cases, New York law would have favored the plaintiff. In Kuehner, the estate of an Ontario domiciliary killed in an Ontario automobile accident involving a New York car insured in New York was denied recovery because of the Ontario guest statute-even though it was perfectly clear that recovery would have been allowed under Tooker $v$. Lopez ${ }^{121}$ had the decedent been a New York domiciliary. Judge Fuld waived away a charge of discrimination in the following words:

To distinguish Tooker on such a basis is not improperly discriminatory. It is quite true that, in applying the Ontario guest statute to the Ontariodormiled passenger we, in a sense, extend a right less generous than New York extends to a New York passenger in a New York vehicle with New York insurance. That, though, is not a consequence of

117. 401 U.S. 985 (1971), rev'g mem., 326 F. Supp. 234 (D. Minn. 1970).

118. A federal district court in Jllinois put it thusly: "The predommant interests to be served on the issue of damages are those of the states containing the people or estates which will receive the recoverable damages, if any, for their injuries or their decedent's death." Manos v. Trans World Airlines, Inc., 295 F. Supp. 1170, 1173 (N.D. MII. 1969).

119. 31 N.Y.2d 121, 286 N.E.2d 454, 335 N.Y.S.2d 64 (1972).

120. 475 F.2d 438 (2d Cir. 1973).

121. 24 N.Y.2d 569, 249 N.E.2d 394, 301 N.Y.S.2d 519 (1969). See text accompanying note 57 supra. 
invidious discrimination; it is, rather, the result of the existence of disparate rules of law in jurisdictions that have important connection with the litigants and the litigated issue. ${ }^{122}$

In Rosenthal, the Second Circuit applied New York substantive law in favor of a New York domiciliary who died in Massachusetts in the hands of a Massachusetts surgeon under circumstances in which it was indisputable that Massachusetts substantive law would have been apphicable had the decedent been a Massachusetts domiciliary. The court accepted the New York pohcy of refusing to apply sister state damage ceilings to limit recoveries by New York domiciliaries involved in out-of-state accidents ${ }^{123}$ - a policy which survived a constitutional due process and full faith and credit attack in Pearson $v$. Northeast Airlines, Inc., ${ }^{124}$ as a "proper exercise of [the state's] power to develop conflict of laws doctrine."125 The Rosenthal court also noted with approval the New York tendency to rely on the domiciliary contact in choosing the law controlling the extent of liability even in cases involving non-citizens. ${ }^{126}$

Finally, in light of the Supreme Court's consistent reluctance to interfere with state choice-of-law rules under the full faith and credit or due process clauses in the past, ${ }^{127}$ there is little reason to expect the Court to embark on a new venture of strict scrutiny of such rules on equal protection or privileges and immunities grounds. ${ }^{128}$

122. Neumeier v. Kuehner, 31 N.Y.2d 121, 125, 286 N.E.2d 454, 456, 335 N.Y.S 2d 64, 68 (1972). Professor Sedler, applying the Currie constitutional analysis (see B. Currie, Selected Essays on the Conflict of Laws (1963)), believes that Neumeier violates the equal protection clause. Sedler, Interstate Accidents and the Unprovided For Case: Reflections on Neumeier v. Kuehner, 1 HofstrA L. REv. 125, 148 (1973). But Currie's suggested approach in this particular area was not only ambiguous but tentative, and he entertained some doubts as to its validity. CurrIE, supra, at 571-72. In any event, eveu if the Neumeier distinction were to be found unconstitutional on equal protection grounds, an extremely unlikely supposition, a no-fault system based on insurance, allocating not only benefits but also responsibilities under the domiciliary laws of the parties involved, would be unuch less likely to suffer the same fate.

123. That policy was originally adopted in the leading case of Kilberg v. Northeast Airlines, Inc., 9 N.Y.2d 34, 172 N.E.2d 526, 211 N.Y.S.2d 133 (1961).

124. 309 F.2d 553 (2d Cir. 1962), cert. denied, 372 U.S. 912 (1963).

125. Id. at 556.

126. In this respect, the court in Rosenthal cited Thomas v. United Airlines, Inc., 24 N.Y.2d 714, 249 N.E.2d 755, 301 N.Y.S.2d 973, cert. denied, 396 U.S. 991 (1969) and Long v. Pan American World Airways, Inc., 16 N.Y.2d 337, 213 N.E.2d 796, 266 N.Y.S.2d 513 (1965).

127. The last time that the Supreme Court invalidated a choice-of-law on constitutional grounds was in Order of Commercial Travelers v. Wolfe, 331 U.S. 586 (1947). See also Kozyris, 403 n.262.

128: Even Professor Sedler concedes that: "[m] is questionable whether the Su- 
Thus, a domicil-based no-fault system, neutrally administered in circumstances where the out-of-stater may fare better under his own law, and closely tied to insurance, ${ }^{129}$ does not appear to involve any recognizable constitutional risk.

\section{CONCLUSION}

With the no-fault concept threatening substantially to replace the tort system for automobile accidents, one would have expected the conflicts scholars to be in the front line of the debate-especially since auto accidents have generated a large share of the more celebrated conflicts cases, as well as many of the new conflicts theories and methodologies. Instead, there is complete silence. The choiceof-law experts continue to engage in transcendental meditation over guest-statutes, ${ }^{130}$ a rather limited and anachronistic exception to negligence liability, ${ }^{131}$ while the state no-fault legislators are bulldozing away progressive conflicts innovations with specific territorially-oriented rules. The traditional penchant of conflicts experts to dissect judicial opinions for vindication of their orthodoxies or heterodoxies rather than to propose specific legislative solutions risking criticism is wellknown. But is this the only explanation? I do not know. It may be that the possibility of a national or a uniform plan, witl the consequent reduction of the conflicts problem, has led to a wait-and-see attitude until the dust settles; or possibly the novelty of the combina-

preme Court will be willing to find limitations on choice of law inherent in the privileges and immunities and equal protection clauses." Sedler, supra note 122, at 148.

According to B. Crampton \& D. Currie, Conflict of Laws-Cases-ComMENTS-QUESTIONS (1968):

Neither Privileges and Immunities nor Equal Protection is firmly established as a limitation upon choice of law; the Currie and Schreter article on the former clause may have been the first of its kind, and the article on equal protection relies upon no Supreme Court cases dealing specifically with choice of law. Indeed these two articles are probably the least understood of the Currie collection .... Id. at 428 .

On the ambiguity and contradiction of the Currie positions in this area, see id. at 426-27.

129. Cf. Shapiro v. Thompson, 394 U.S. 618, 633 n.10 (1969), the welfare benefits case discussed in text accompanying note 114 supra, where the Court stated that "We are not dealing here with state insurance programs which may legitimately tie the amount of benefits to the individual's contributions."

130. See, e.g., learned symposia on Cipolla v. Shaposka, 439 Pa. 563, 267 A.2d 854 (1970) in 9 DUQUESNE L. REv. 347-465 (1971); Foster v. Leggett, 484 S.W.2d 827 (Ky. 1972) in $61 \mathrm{KY}$. L.J. 368-428 (1973); and Neumeier v. Kuehner, 31 N.Y.2d 121, 286 N.E.2d 454, 335 N.Y.S.2d 64 (1972) in 1 HoFsTRA L. Rev. 93-182 (1973).

131. The California guest statute has been declared unconstitutional for violation of the equal protection clause. Brown v. Merlo, 8 Cal. 3d 855, 506 P.2d 212, 106 Cal. Rptr. 388 (1973). 
tion of tort and insurance features inakes the problem especially difficult to handle and deters people from enbarking on the enterprise. Whatever the cause, no-fault is surging ahead without the benefit of a full conflicts discussion, and, once the rules crystallize, it will be rather difficult to do much more than attempt to interpret thein, probing for, and speculating about, a legislative intention which may never have existed. 